\title{
Liter per Gram per Day
}

National Cancer Institute

\section{Source}

National Cancer Institute. Liter per Gram per Day. NCI Thesaurus. Code C85657.

Liters per gram per day. 